\title{
Potentiometric determination of mercury (II) ion in various real samples using novel modified screen-printed electrode
}

\author{
Refaat F. Aglan ${ }^{1} \cdot$ Hosam M. Saleh ${ }^{2} \cdot$ Gehad G. Mohamed ${ }^{3,4}$ \\ Received: 21 March 2018 / Accepted: 2 August 2018 / Published online: 12 August 2018 \\ (c) The Author(s) 2018
}

\begin{abstract}
A screen-printed electrode modified with zirconium antimonate ionophore was fabricated for the quantification of $\mathrm{Hg}$ (II) ion. The modified electrode revealed linear response in a wide concentration range of $5 \times 10^{-8}-1 \times 10^{-1} \mathrm{~mol} / \mathrm{L}$ at $25^{\circ} \mathrm{C}$ of $\mathrm{Hg}$ (II) with a slope of $30.02 \pm 0.75 \mathrm{mV} /$ decade with detection limit of $5 \times 10^{-8} \mathrm{~mol} / \mathrm{L}$. The electrode can be used in the $\mathrm{pH}$ range 2.5-8.5. Selectivity coefficients were assessed using fixed interference and matched potential techniques. The electrode stability was maintained for 16 weeks. This modified electrode was allowed to determine $\mathrm{Hg}$ (II) ions in different media such as water, dental amalgam and fish tissue. An inductively coupled plasma-optical emission spectrometry confirmed the efficiency and accuracy of the nominated modified electrode.
\end{abstract}

Keywords Screen-printed ion-selective electrode $\cdot$ Zirconium antimonate ionophore $\cdot$ Mercury determination $\cdot$ Water samples

\section{Introduction}

The heavy metal contamination has attracted global interest as serious environmental matter due to its toxicity, bioaccumulation, abundance and persistence. Mercury as one of the most hazardous metals was detected since ancient ages, and mercury was remained and was found in the Egyptian tombs (1500 BC).

Production of nuclear fuel needed uranium enrichment and isotope separation. This process was considered a

Hosam M. Saleh

hosamsaleh70@yahoo.com; hosam.saleh@eaea.org.eg

Refaat F. Aglan

refat_fekryaglan@yahoo.com

Gehad G. Mohamed

ggenidymohamed@sci.cu.edu.eg

1 Analytical Chemistry and Environmental Control Department, Hot Laboratories Center, Atomic Energy Authority, Inshas 13759, Egypt

2 Radioisotope Department, Nuclear Research Center, Atomic Energy Authority, Dokki, Giza, 12311, Egypt

3 Chemistry Department, Faculty of Science, Cairo University, Giza 12613, Egypt

4 Egypt Nanotechnology Center, Cairo University, El-Sheikh Zayed, 6th October 12588, Egypt common source of mercury (Riley et al. 1992). People accumulated mercury from food chain, industrial wastes, amalgam compounds and environmental pollution. $\mathrm{Hg}$ is very toxic due to adverse action on enzymes in the living body resulting in blindness, paralysis, neurological destruction, serious troubles for human health and animals (Halbrook et al. 1994; Manahan 1979).

Mercury, one of the best-known highly toxic contaminants occurring in various environments, was considered a carcinogenic and caustic material (Lou et al. 2013). It was frequently released from combustion of fossil fuels and electronic waste, power plants, breaking of $\mathrm{Hg}$ (II) products and medical wastes. In step with its hazards such as prolonged existence time, high recalcitrance, accumulation and longtime retention in biological systems, many biomolecules such as proteins, enzymes, lipids and DNA were obstructed. Thus, this leads to neurological or neurophysiological disorders, damage of the respiratory and cardio vascular system and the gastro intestinal tract (Ma et al. 2015; Bhanjana et al. 2015).

Based on the above statements, the maximum threshold limit value of $\mathrm{Hg}$ (II) ions in drinking water was prescribed to be 2 ppb according to the World Health Organization (WHO) and the Environmental Protection Agency (EPA) (WHO 2004). Consequently, selective and sensitive 
analysis of $\mathrm{Hg}(\mathrm{II})$ was important in environmental monitoring, food safety and clinical toxicology (Chen et al. 2011).

Distinctive analytical methods, including cold vapor atomic absorption spectrometry (Martinis et al. 2009; Zavvar Mousavi et al. 2010; Ferrúa et al. 2007), X-ray fluorescence spectrometry (de Wuilloud et al. 2002), inductively coupled plasma mass spectrometry (dos Santos et al. 2005; Lau and Ho 1993), inductively coupled plasma-optical emission spectrometry (Wuilloud et al. 2004; Matousek et al. 2002) and cold vapor atomic fluorescence spectrometry (Bagheri and Gholami 2001; Jiang et al. 2010; Zi et al. 2009) were used in order to detect mercury at trace quantities in different samples. Unfortunately, these methods had a number of significant drawbacks, like the need for costly equipment, cost-intensive and cumbersome operation procedures and exhaustive maintenance efforts.

Based on many benefits of using potentiometric sensors such as high sensitivity, low cost, simplicity in use and fast response time, ion-selective electrodes found many applications in electroanalytical chemistry including the detection of hazardous pollutants such as mercury even at trace levels (Agrahari et al. 2014). Valve metals such as Ta, Zr, $\mathrm{Hf}$ and Ti have high resistivity to corrosion when located in acidic or basic media due to the covering of their surfaces by a thin barrier oxide film. Zirconium was a metal of great applications in the nuclear and chemical fields (Ghoneim et al. 1996, 1998).

The purpose of the present work is to evaluate a screenprinted electrode (SPE) modified with zirconium antimonate ionophore as one of the highly selective and sensitive electrodes prepared for potentiometric determination of $\mathrm{Hg}$ (II) in different aqueous media. The screen-printed electrode was successfully applied for the determination of $\mathrm{Hg}$ (II) ions in water, dental amalgam and fish tissue samples.

\section{Experimental}

\section{Chemicals and reagents}

Bi-distilled water and reagents of analytical grade were used throughout all experiments presented in this paper. Mercury chloride was purchased from Merck. Zirconium oxy-chloride (Rankem, Mumbai, India), potassium pyroantimonate (CHD, New Delhi, India), and o-nitro-phenyloctylether $(o$-NPOE) and sodium tetraphenylborate (NaTPB) were purchased from Fluka. $\mathrm{HCl}, \mathrm{HNO}_{3}, \mathrm{NaOH}$, dioctylphthalate (DOP), dibutylphthalate (DBP) and dioctylsebacate (DOS) was purchased from BDH. Tricresylphosphate (TCP), PVC (relatively high molecular weight) and graphite powder (synthetic $1-2 \mu \mathrm{m}$ ) were provided from Aldrich.

\section{Equipment/apparatus}

A Jenway $3505 \mathrm{pH}$-meter was used for potentiometric measurements. The $\mathrm{pH}$-meter was equipped with a reference electrode $(\mathrm{Ag}-\mathrm{AgCl}$ double-junction, Metrohm 6.0726.100), which was connected with the proposed ionselective electrode. $\mathrm{pH}$ detection was done by ThermoOrion, model Orion 3 stars, USA. An inductively coupled plasma-optical emission spectrometry (ICP-OES) was applied as reference method to detect metal ions.

\section{Preparation of zirconium antimonate ionophore}

Zirconium antimonate was synthesized by dropwise addition of $0.5 \mathrm{M}$ potassium pyroantimonate $(200 \mathrm{~mL})$ into $0.5 \mathrm{M}$ aqueous solution of zirconium oxy-chloride $(200 \mathrm{~mL})$ under continuous stirring. At the end of the addition process, a white precipitate was obtained.

The reaction mixture was diluted to $1 \mathrm{~L}$, and cured for one day for complete digestion. The supernatant solution was decanted and precipitate was filtered by suction and the remaining acid residues were removed by well rinsing with hot water. The purified precipitate was then dried by gentle heating at $60 \pm 1{ }^{\circ} \mathrm{C}$. After drying, the solid product was poured in distilled water and heated to $80 \pm 1{ }^{\circ} \mathrm{C}$ to break the solid and remove air trapped inside the solid product; then, it was again subjected to drying at $60 \pm 1{ }^{\circ} \mathrm{C}$. The obtained solidified material was ground, sieved and stored at ambient temperature (Elkady et al. 2015).

\section{Preparation of screen-printed electrode}

A manual screen printer was used to prepare the array of twelve electrodes by printing of the conductive ink through the screen stencil onto X-ray film. A sheet consisting of stainless steel was tempered to a steel mold; this sheet contained furrows corresponding to the electrode's size (Ali et al. 2014). The ink used for printing was produced by combining the $1 / 1$ cyclohexanone/acetone mixture, acting as a solvent for the bonding agent, with $450 \mathrm{mg}$ o-NPOE, $1.25 \mathrm{mg}$ poly(vinyl chloride), and $0.75 \mathrm{mg}$ charcoal (synthetic $1-2 \mu \mathrm{m})(0.75 \mathrm{mg})$; afterward, $7.5 \mathrm{mg}$ of zirconium antimonate was supplemented. This was followed by stirring (15 min) and sonicating. Finally, the ink was ready to be used to print the prepared electrodes (Frag et al. 2016). Plasticizer selection has a potential impact on the electrode performance. In this study, the electrode was plasticized with o-NPOE and compared with other electrodes plasticized with DBP, DOS, DOP and TCP. The proposed electrodes were allowed to dry at room temperature and then covered 
with a layer of insulator. The suitable temperature for storing the nominated electrodes was at $4{ }^{\circ} \mathrm{C}$.

\section{Measuring the potential}

Solutions to be tested were agitated. Sensor response for the mercury ion was monitored by determining the electromotive force (emf) of the following electrochemical cell: $\mathrm{Ag}|\mathrm{AgCl}| \mathrm{KCl}$ (saturated)\|sample solution|SPE. For evaluating the results, the measured emf was plotted against the logarithm of mercury(II) ion concentration. At the point of intersection of the extrapolated linear segments of the calibration curve, the detection limit was defined. The selectivity coefficients $\left(K_{\mathrm{Hg}, \mathrm{J}}^{\mathrm{pot}}\right)$ were determined by using the fixed interference (Umezawa et al. 1995, 2000) and matched potential methods (Raulf et al. 1995; Antropov 1972) using $\mathrm{Hg}$ (II) $(0.001 \mathrm{~mol} / \mathrm{L})$ and interfering ions. $1 \mathrm{M} \mathrm{HCl}$ or $\mathrm{NaOH}$, respectively, were used to adjust the $\mathrm{pH}$-value of the $\mathrm{Hg}$ (II) solution. Mercury chloride solution was serially diluted to obtain concentrations from $10^{-1}$ to $10^{-8} \mathrm{~mol} / \mathrm{L}$. An inductively coupled plasma-optical emission spectrometry (ICP-OES) was used to evaluate the standard concentrations.

\section{Sample preparation}

In order to demonstrate the applicability and reliability of the proposed mercury sensitive sensor, different real samples, including tap water, river water, industrial wastewaters, waste of dental amalgam and fish tissue were prepared and subjected to analysis.

The collected samples of water and wastewater were subjected to filtration through a filter paper (Whatman No. 40). Dilute solution of nitric acid or sodium hydroxide was used to adjust $\mathrm{pH}$ of the samples to the desired values (Afkhami et al. 2012). Ten milliliters of tested solutions was used for the analyses.

Silver, tin, copper and zinc amalgams of mercury are used to fill teeth result in dental amalgam wastes. This waste was prepared in this study due to the previously published article (Gupta et al. 2007). Amalgam materials were ground to small pieces and digested with nitric acid. The sample solution obtained by this way was diluted to $100.0 \mathrm{~mL}$ using double distilled water and then adjusted to the optimal $\mathrm{pH}$ before introducing to the following process to determine the mercury content using the proposed electrode and ICP-OES.

The feasibility of the reported sensor was tested to determine mercury ions in fish tissue sample. A sample of $1.0 \mathrm{~g}$ dried fish tissue, locally purchased, was subjected to digestion vessel including $5.0 \mathrm{~mL}$ of $\mathrm{HNO}_{3}$ and $6.0 \mathrm{~mL}$ of $\mathrm{H}_{2} \mathrm{O}_{2}$. The content of the vessel was gently swirled and heated at $180{ }^{\circ} \mathrm{C}$ for $90 \mathrm{~min}$. (Afkhami et al. 2012). Then $6.0 \mathrm{~mL}$ of
$1.0 \mathrm{~mol} \mathrm{~L}{ }^{-1} \mathrm{~K}_{2} \mathrm{~S}_{2} \mathrm{O}_{8}$ was added and heated again for $30 \mathrm{~min}$. The digested sample was cooled at room temperature, and then, the $\mathrm{pH}$ of the sample solution was adjusted at optimal $\mathrm{pH}$ and quantitatively diluted with appropriate amount of bi-distilled water. Finally, an aliquot of this solution was used for $\mathrm{Hg}$ (II) ions determination using $\mathrm{Hg}(\mathrm{II})$-MSPE sensor and ICP-OES.

\section{Results and discussion}

Preliminary studies focused on zirconium antimonate as an electroactive compound in modified screen-printed electrode (MSPE) to be used to determine a variety of diverse ions of metal, encompassing ions of alkali metals, alkaline earth metals, transition metals and heavy metals. In case of such zirconium antimonate-based SPEs, potential response values were collected separately for each individual ion. Figure 1 clearly shows a highly sensitive response of MSPE to $\mathrm{Hg}$ (II) ions; this underlines the suitability of the electrode prepared from zirconium antimonate for evaluation of $\mathrm{Hg}$ (II) ions. The response characteristics of the proposed $\mathrm{Hg}$ (II)-MSPE were systematically evaluated according to the IUPAC recommendation (Buck and Lindner 1994).

The calibration plot obtained showed a linear relation between measured emf and logarithm of mercury(II) concentration within the range from $5 \times 10^{-8}$ to $1 \times 10^{-1} \mathrm{~mol} \mathrm{~L}^{-1}$, with a cationic slope of $30.02 \pm 0.75 \mathrm{mV} /$ decade (Fig. 1), The lower limit of measurement was approximately $5 \times 10^{-8}$ mol L ${ }^{-1} \mathrm{Hg}(\mathrm{II})$ ions. Table 1 summarizes the response characteristics of the electrode.

\section{Effect of ionophore content}

It is well known that the membrane composition is a significant parameter for the electrode, when the amount of sensing material of the matrix such as zirconium antimonate was appropriate to implement sensible ionic exchange (selective extraction of the evaluated ion). The chemical equilibrium at the membrane of electrode/solution interface will be responsible for the electrode potential. The impact of the sensing material on the performance of proposed electrode was studied.

In this context, five electrodes containing distinct amounts of the ionophore $(5-15 \mathrm{mg})$ have been prepared. As it is well visible from Fig. 2, $12.5 \mathrm{mg}$ can be regarded as the optimum ionophore load. Higher ionophore loads resulted in an increase in the calibration curve's slope until a definite point; after that, the slope decreased for all examined electrodes. The response of the suggested sensor has been attributed to an exchange process of $\mathrm{Hg}$ (II) ions between the analyzed aqueous solution and the solvent mediator. The equilibrium of the system was achieved when the electrochemical

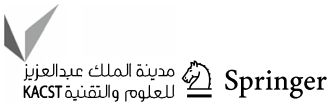


Fig. 1 Potential response of modified SPEs based on zirconium antimonate for various metals

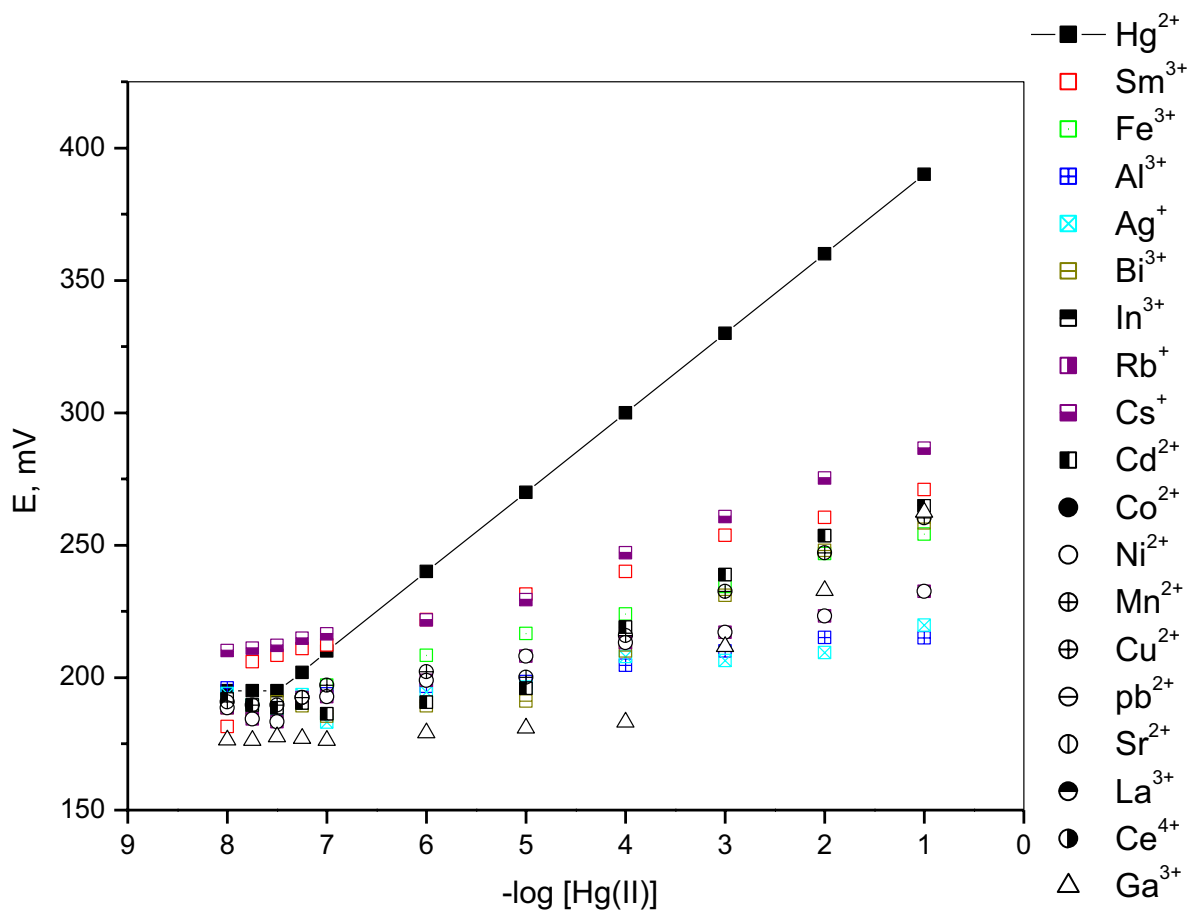

Table 1 Response characteristics of modified MSPE sensor

\begin{tabular}{|c|c|}
\hline Parameter & SPE \\
\hline Slope $\left(\mathrm{mV}\right.$ decade $\left.{ }^{-1}\right)$ & $30.02 \pm 0.75$ \\
\hline Concentration range & $5 \times 10^{-8}-1 \times 10^{-1}$ \\
\hline Correlation coefficient, $r$ & 0.999 \\
\hline Lower detection limit $\left(\mathrm{mol} \mathrm{L}^{-1}\right)$ & $5 \times 10^{-8}$ \\
\hline Upper detection limit $\left(\mathrm{mol} \mathrm{L}^{-1}\right)$ & $1 \times 10^{-1}$ \\
\hline Working $\mathrm{pH}$ range & $2.5-8.5$ \\
\hline Intercept (mV) & 392.71 \\
\hline Lifetime (weeks) & 16 \\
\hline Response time (s) & $<10$ \\
\hline SD of slope $\left(\mathrm{mV}\right.$ decade $\left.{ }^{-1}\right)$ & 0.16 \\
\hline
\end{tabular}

$N=4$

potential of $\mathrm{Hg}$ (II) ions in the two phases were equal and the $\mathrm{Hg}$ (II) ions in the aqueous phase did not influence the activity of the ions in the organic phase (Gurtova et al. 2013).

\section{Effect of plasticizer type}

ISEs performance is to a high extent dictated by the type of plasticizer used, because the plasticizer enhances the sensing material's solubility, and, based on their polarity characteristics, influences the electrode's general bulk resistance. The plasticizer impact on performance of the proposed electrode has been evaluated. In this case, the electrode performed with o-NPOE in comparison with those of TCP, DBP, DOP and DOS was studied.

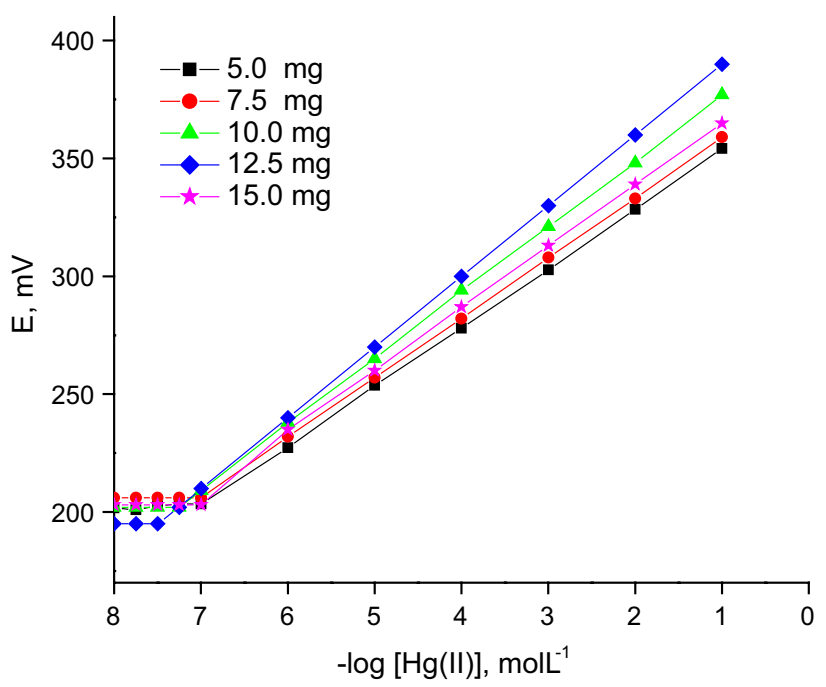

Fig. 2 Effect of ionophore content on calibration of the modified SPE sensor

The obtained calibration graph with various plasticizers indicated that o-NPOE as plasticizer resulted in highly sensitive membrane electrode with the highest slope and wider linear range related to the dielectric constant of these plasticizers (where $\varepsilon$ value equals to $24,3.88,4.7$, 5.2, and 17.6 for the tested plasticizers in the same order). These features are shown in Fig. 3. 


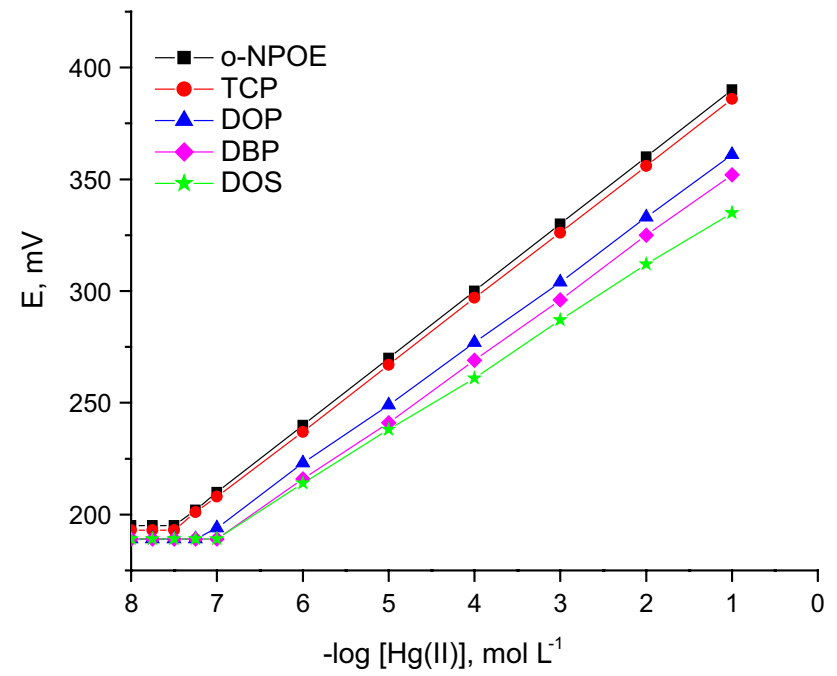

Fig. 3 Effect of plasticizer type on calibration of the modified SPE sensor

\section{Dynamic response time}

The electrode's response time is a critical factor for analytical uses. The operation time is understood as the time span, which elapses between dipping the electrode in the measuring solution and reaching the equilibrium potential. In addition, the average time needed by the electrode to attain a steady potential response of the ultimate equilibrium value with a deviation of $\pm 1 \mathrm{mV}$ has also to be considered.

Following a sequential dipping in $\mathrm{Hg}$ (II) solutions differing in their concentrations by a factor of 10 , the measurement results were evaluated. Response time inherent to SPEs are only measurable if the overall response time of the potentiometric system is governed by the properties of the paste of electrode, i.e. if the time constant of the response function of the electrode is much larger than the time constant of the electrochemical cell and the electronic EMF-measuring device. As a matter of fact, the entire response time is determined by many factors, such as the measuring instrument's time constant, the ion transfer reaction rate through the paste-pattern interface, the impedance of the equivalent electric circuit of the paste or the stabilization of a liquid-junction potential at the reference electrode (Umezawa et al. 1995).

It can be clearly delineated from the results that all the potentiometric response times of the nominated electrode were less than $10 \mathrm{~s}$ within the concentration range of $10^{-6}-10^{-3} \mathrm{~mol} \mathrm{~L}^{-1} \mathrm{Hg}$ (II) (Fig. 4). This quick response time was in excellent agreement with previous results reporting that electrodes containing carbon particles and surrounded by a very thin film of o-NPOE behave as a conductor (Raulf et al. 1995).

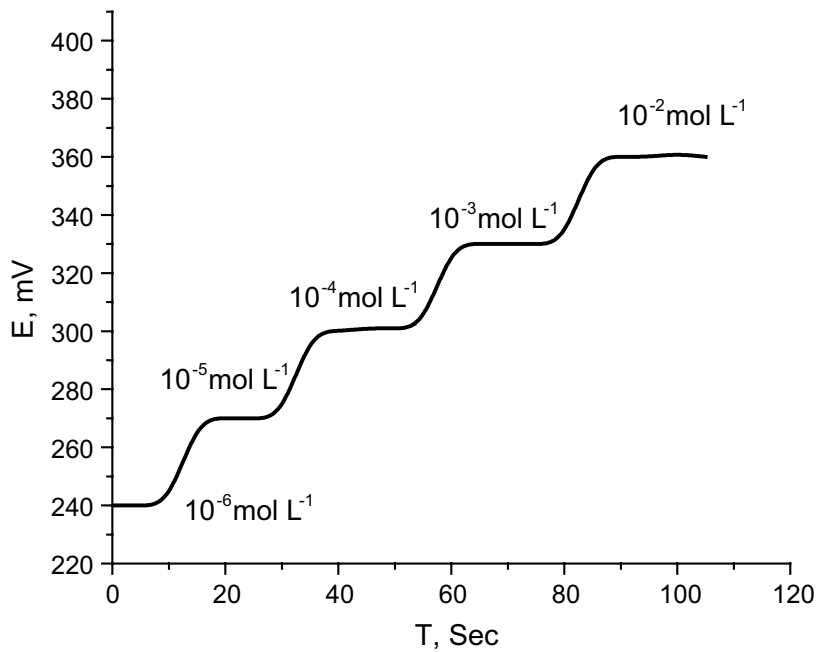

Fig. 4 Dynamic response time of $\mathrm{Hg}(\mathrm{II})$ modified SPE sensor

\section{Effect of pH}

The impact of the pH-value on the response of the SPE was investigated by analyzing the cell's potential readings for solutions containing $\mathrm{Hg}(\mathrm{II})$ in concentrations $10^{-4}$ and $10^{-3} \mathrm{~mol} / \mathrm{L}$ and $\mathrm{pH}$-values between 1 and 10 . Tiny quantities of $0.1-1 \mathrm{M} \mathrm{HCl}$ or $\mathrm{NaOH}$, respectively, were added to $10 \mathrm{~mL}$ of the $\mathrm{Hg}(\mathrm{II})$ solution in order to vary the $\mathrm{pH}$-value. The resulting $\mathrm{E}$ values $[\mathrm{mV}]$ were plotted against the corresponding $\mathrm{pH}$-values. Accordingly, it was obvious that the electrodes performed independent of the $\mathrm{pH}$-value in the range between $\mathrm{pH} 2.5$ and $\mathrm{pH}$ 8.5. The potential within this range tends to be constant with nearly zero percent of change in $\mathrm{mV}$ value (Fig. 5). On the other hand, at lower

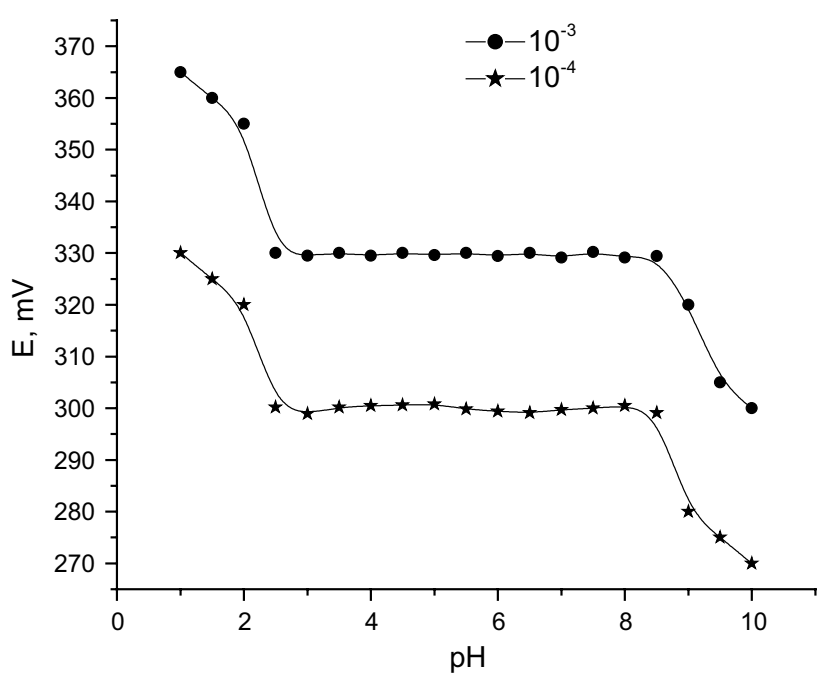

Fig. 5 Effect of $\mathrm{pH}$ of the test solution on the potential readings of modified SPE sensor 
and upper of this range, the measurement efficiency could be affected by the formation of some hydroxyl complexes of $\mathrm{Hg}$ (II) ion at high $\mathrm{pH}$ (more than 8.5) and by the hydrogen ion response at low $\mathrm{pH}$ (less than 2.5), accompanying with less than $10 \%$ change in $\mathrm{mV}$ value.

\section{Effect of temperature}

Calibration curves (electrode potential $\left(E_{\text {elec }}\right)$ versus $p[\mathrm{Hg}(\mathrm{II})])$ were established at various testing solution temperatures $\left(10,25,30,40,50\right.$ and $\left.60{ }^{\circ} \mathrm{C}\right)$. To detect the isothermal coefficient of the electrode $\left(\mathrm{d} E^{0} / \mathrm{d} T\right)$, the standard electrode potentials $\left(E^{0}\right)$ versus the normal hydrogen electrode at varying temperatures were implemented from calibration curves as the intercepts at $p[\mathrm{Hg}(\mathrm{II})]=0$ and plotted against $(t-25)$, where $t$ is the temperature of the testing solution in ${ }^{\circ} \mathrm{C}$ (Fig. 6). Accordingly, a straight-line graph could be computed due to Antropov's equation (1972). $E_{\text {cell }}^{0}=E_{\text {cell }\left(25^{\circ} \mathrm{C}\right)}^{0}+\left[\left(\mathrm{d} E^{0}\right)_{\text {cell }} / \mathrm{d} t\right](t-25)$, where $E_{(25)}^{0}$ is the standard electrode potential at $25{ }^{\circ} \mathrm{C}$.

The slope of the straight line represents the isothermal coefficient of the electrodes. The nominated electrode was detected with isothermal coefficient of $0.0984 \mathrm{mV} /{ }^{\circ} \mathrm{C}$. Based on the isothermal coefficient value of the proposed electrode, it could be stated that the thermal stability of the electrode was quite high within the applied temperature range. In this manner, the candidate electrode could be considered for using fairly up to $60{ }^{\circ} \mathrm{C}$ with undetectable deviation from the Nearnstian behavior.

\section{Selectivity and interference}

Selectivity could be the most significant property of the electrode that defines the range in which it works accurately to determine one specified ion mixed with a matrix

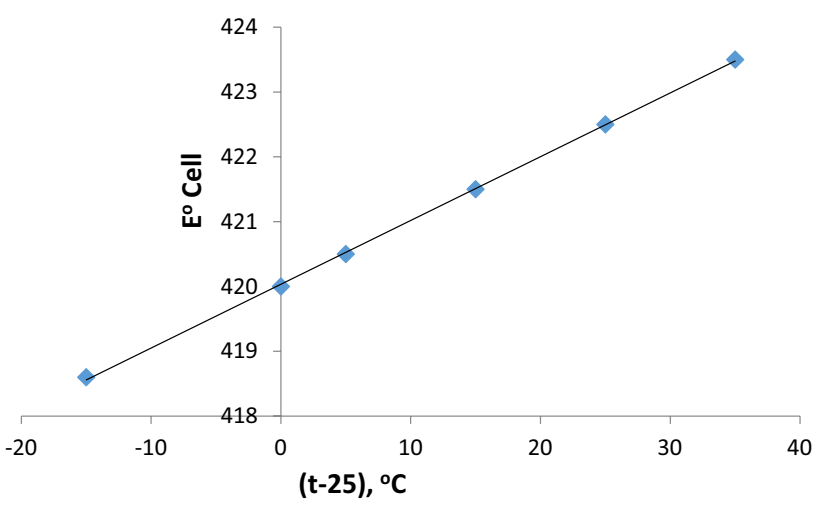

Fig. 6 Variation of the cell emf with the temperature for the modified SPE sensor of other species acting as interfering ions. Potentiometric selectivity coefficients of the $\mathrm{Hg}$ (II) electrode were evaluated by "fixed interference method" (FIM) (Umezawa et al. $1995,2000)$ at $10^{-3} \mathrm{M}$ concentration of the interfering ions and "matched potential method" (MPM) (Raulf et al. 1995; Antropov 1972) that was recommended by IUPAC. The matched potential method is characterized by overcoming the disadvantages accompanying with other methods in accordance with the Nicolsky-Eisenman equation. By using this process, the reference solution was added to the specified activity of primary ion (A) before measuring the potential. On the other hand, interfering ion (B) has to be added successively to the identical reference solution including the primary ion, until the potential value is reached that is obtained with the primary ions separately. The results shown in Table 2 manifested the high selectivity for $\mathrm{Hg}(\mathrm{II})$ ion without interference from the other studied cations using the proposed electrode.

\section{Lifetime of screen-printed electrode}

The lifetime of the electrode was evaluated by performing calibrations periodically with standard solutions and calculating the slopes over the concentration ranges from $10^{-8}$ to $10^{-1} \mathrm{~mol} / \mathrm{L}$ of $\mathrm{Hg}(\mathrm{II})$ solutions over a period of 20 weeks. The experimental results showed that, the slope

Table 2 Potentiometric selectivity coefficients of some interfering ions using the modified SPE sensor

\begin{tabular}{lll}
\hline Interfering ions (B) & \multicolumn{1}{l}{ pot } & \\
\cline { 2 - 3 } & FIM & MPM \\
\hline $\mathrm{Sm}^{3+}$ & $2.72 \times 10^{-3}$ & $4.75 \times 10^{-3}$ \\
$\mathrm{Cd}^{2+}$ & $2.85 \times 10^{-4}$ & $4.85 \times 10^{-4}$ \\
$\mathrm{Fe}^{3+}$ & $1.01 \times 10^{-2}$ & $5.02 \times 10^{-2}$ \\
$\mathrm{Zn}^{2+}$ & $2.50 \times 10^{-5}$ & $7.52 \times 10^{-5}$ \\
$\mathrm{NH}_{4}^{+}$ & $1.21 \times 10^{-5}$ & $6.25 \times 10^{-5}$ \\
$\mathrm{Mg}^{2+}$ & $4.50 \times 10^{-6}$ & $2.55 \times 10^{-6}$ \\
$\mathrm{La}^{3+}$ & $5.99 \times 10^{-5}$ & $1.95 \times 10^{-5}$ \\
$\mathrm{Ni}^{2+}$ & $5.99 \times 10^{-6}$ & $5.95 \times 10^{-6}$ \\
$\mathrm{pb}^{2+}$ & $4.22 \times 10^{-4}$ & $3.28 \times 10^{-4}$ \\
$\mathrm{Li}^{+}$ & $1.25 \times 10^{-3}$ & $7.28 \times 10^{-3}$ \\
$\mathrm{Ba}^{2+}$ & $7.94 \times 10^{-3}$ & $3.98 \times 10^{-3}$ \\
$\mathrm{Ca}^{2+}$ & $8.10 \times 10^{-3}$ & $4.18 \times 10^{-3}$ \\
$\mathrm{~K}^{+}$ & $9.10 \times 10^{-2}$ & $5.18 \times 10^{-2}$ \\
$\mathrm{Co}^{2+}$ & $6.34 \times 10^{-3}$ & $1.38 \times 10^{-3}$ \\
$\mathrm{Na}^{+}$ & $1.22 \times 10^{-3}$ & $5.28 \times 10^{-3}$ \\
$\mathrm{Rb}^{+}$ & $3.22 \times 10^{-3}$ & $7.28 \times 10^{-3}$ \\
$\mathrm{Mn}^{2+}$ & $2.85 \times 10^{-5}$ & $8.88 \times 10^{-5}$ \\
$\mathrm{Al}^{3+}$ & $1.01 \times 10^{-5}$ & $6.08 \times 10^{-5}$ \\
$\mathrm{Cu}^{2+}$ & $8.50 \times 10^{-4}$ & $2.58 \times 10^{-4}$ \\
$\mathrm{Sr}^{2+}$ & $6.21 \times 10^{-4}$ & $1.28 \times 10^{-4}$ \\
\hline & &
\end{tabular}




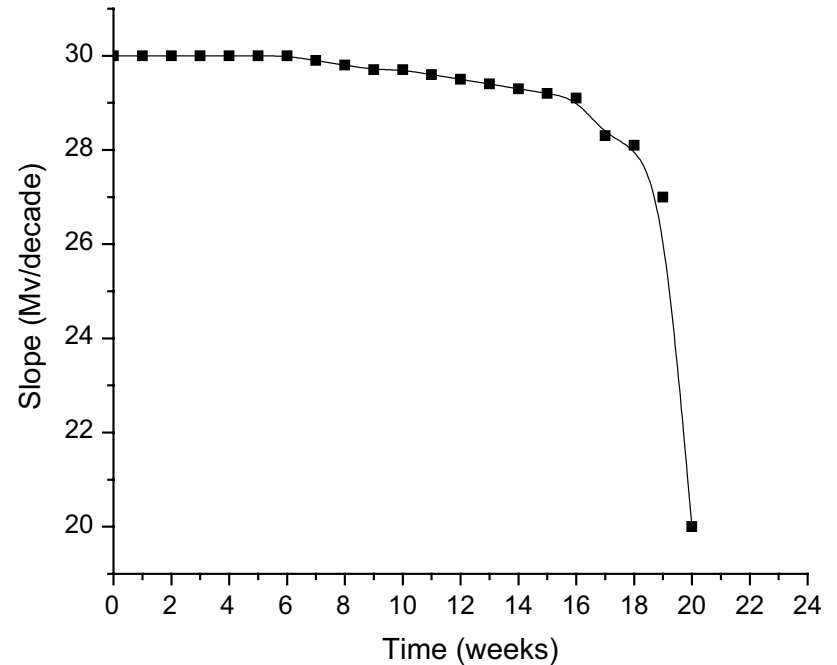

Fig. 7 Lifetime of the $\mathrm{Hg}$ (II) modified SPE sensor

of the electrode $(30.02 \pm 0.75 \mathrm{mV} /$ decade change) showed a gradual decrease after 16 weeks (Fig. 7). It can therefore be concluded that the lifetime of the proposed electrode was at least 16 weeks. After this period, the slight change in the observed slope could be corrected by conditioning the SPE with $0.01 \mathrm{~mol} / \mathrm{L} \mathrm{Hg}(\mathrm{II})$ solution for 1-3 days. With this treatment, the assembly could be used for 2 weeks more. The lifetime of SPE mainly depends on the type of ion pair and plasticizers used, and on the number of times used (Sadeghi et al. 2002). After 18 weeks, the electrode response deteriorated, which may be attributed to the aging of the SPE matrixes, ion pair, as well as plasticizer (Oesch and Simon 1980).

\section{Analytical applications}

The proposed sensor $\mathrm{Hg}(\mathrm{II})$-MSPE was successfully applied for the determination of mercury(II) ions at trace levels in a wide variety of real samples. Tap water, river water, industrial wastewaters, the waste of dental amalgam and fish tissue samples were treated by the recommended procedures, and analyzed by the suggested potentiometric sensor. The results are given in Table 3. According to this table, the obtained results were comparable with those obtained by (ICP-OES). Thus, the sensor provided a good alternative for the determination of $\mathrm{Hg}$ (II) in different real samples.

\section{Method validation}

Validation of electroanalytical techniques constitutes a procedure established to check if a determination technique applied for specific measurements is appropriate for its designated purpose similar to alternative techniques (Gumustas and Ozkan 2011). Validation studies to confirm accuracy, detection limits, measurement limits, linearity, precision and specificity were carried out applying standard $\mathrm{Hg}(\mathrm{II})$-stock solutions.

\section{Accuracy and precision}

Accuracy and precision may be defined as the most nearly to the same values that is validated, whatever as a traditional, true or accepted reference value, and the value found (Gumustas and Ozkan 2011). Intra-day and inter-day precisions were recorded using four replicates of two concentrations. The relative standard deviations were evaluated as very small values with regard to the reasonable repeatability of the nominated method as presented in Table 4.

Precision is defined as the level of consistency between the results of solely tests through applying the process repeatedly to multiple samplings of a homogeneous specimen. Moreover, precision is generally described as standard or relative standard deviations (RSD) of the replicate analysis (Oesch and Simon 1980). Hence, the precision of nominated potentiometric method was measured as percentage relative standard deviation (RSD \%) using the sensors under evaluation. Table 3 includes the RSD\% values for the repeated determinations.
Table 3 Potentiometric determination of $\mathrm{Hg}(\mathrm{II})$ in different real samples using modified SPE sensor

\begin{tabular}{|c|c|c|c|c|c|c|c|}
\hline \multirow[t]{2}{*}{ Samples } & \multirow{2}{*}{$\begin{array}{l}\text { Taken }[\mathrm{Hg}(\mathrm{II})] \text {, } \\
\text { mol L }^{-1}\end{array}$} & \multicolumn{2}{|c|}{ Found $[\mathrm{Hg}(\mathrm{II})], \mathrm{mol} \mathrm{L}^{-1}$} & \multicolumn{2}{|l|}{$R(\%)$} & \multicolumn{2}{|c|}{$\operatorname{RSD}(\%)$} \\
\hline & & ICP-OES & SPE & ICP-OES & SPE & $\begin{array}{l}\text { ICP- } \\
\text { OES }\end{array}$ & SPE \\
\hline Tap water & $1 \times 10^{-6}$ & $9.90 \times 10^{-7}$ & $9.63 \times 10^{-7}$ & 99.00 & 96.30 & 0.41 & 0.32 \\
\hline River water & $1 \times 10^{-6}$ & $9.95 \times 10^{-7}$ & $9.72 \times 10^{-7}$ & 99.50 & 97.20 & 0.61 & 0.67 \\
\hline Industrial wastewater & $1 \times 10^{-6}$ & $9.93 \times 10^{-7}$ & $9.68 \times 10^{-7}$ & 99.30 & 96.80 & 0.52 & 0.35 \\
\hline Dental amalgam & $1 \times 10^{-6}$ & $9.85 \times 10^{-7}$ & $9.75 \times 10^{-5}$ & 98.50 & 97.50 & 0.41 & 0.48 \\
\hline Fish tissue & $1 \times 10^{-6}$ & $9.97 \times 10^{-7}$ & $9.79 \times 10^{-5}$ & 99.70 & 97.90 & 0.54 & 0.69 \\
\hline
\end{tabular}

$N=4$ 
Table 4 Evaluation of intra- and inter-day precision and accuracy of the modified SPE sensor

\begin{tabular}{|c|c|c|c|c|c|c|c|c|c|}
\hline \multirow[t]{2}{*}{ Samples } & \multirow{2}{*}{$\begin{array}{l}{[\mathrm{Hg}(\mathrm{II})]} \\
\text { taken }(\mathrm{mg} / \\
\mathrm{mL})\end{array}$} & \multicolumn{4}{|l|}{ Intra-day } & \multicolumn{4}{|l|}{ Inter-day } \\
\hline & & $\begin{array}{l}\mathrm{Hg}(\mathrm{II}) \text { found } \\
(\mathrm{mg} / \mathrm{mL})\end{array}$ & Recovery (\%) & SD & $\operatorname{RSD}^{\mathrm{a}}(\%)$ & $\begin{array}{l}\mathrm{Hg}(\mathrm{II}) \text { found } \\
(\mathrm{mg} / \mathrm{mL})\end{array}$ & Recovery (\%) & SD & $\operatorname{RSD}^{\mathrm{b}}(\%)$ \\
\hline \multirow[t]{2}{*}{ Pure solution } & 0.75 & 0.747 & 99.60 & 0.002 & 0.27 & 0.748 & 99.70 & 0.003 & 0.4 \\
\hline & 1.50 & 1.495 & 99.66 & 0.033 & 2.20 & 1.497 & 99.80 & 0.02 & 1.33 \\
\hline \multirow[t]{2}{*}{ Tap water } & 0.75 & 0.748 & 98.80 & 0.004 & 0.54 & 0.748 & 99.70 & 0.001 & 0.133 \\
\hline & 1.50 & 1.490 & 99.30 & 0.024 & 1.61 & 1.483 & 98.90 & 0.024 & 1.62 \\
\hline \multirow[t]{2}{*}{ River water } & 0.75 & 0.746 & 99.50 & 0.003 & 0.4 & 0.742 & 99.00 & 0.003 & 0.40 \\
\hline & 1.50 & 1.488 & 99.20 & 0.035 & 2.35 & 1.470 & 98.00 & 0.032 & 2.18 \\
\hline \multirow[t]{2}{*}{ Industrial wastewater } & 0.75 & 0.745 & 99.40 & 0.004 & 0.54 & 0.739 & 98.50 & 0.003 & 0.40 \\
\hline & 1.50 & 1.471 & 98.10 & 0.027 & 1.84 & 1.487 & 99.10 & 0.031 & 2.08 \\
\hline \multirow[t]{2}{*}{ Dental amalgam } & 0.75 & 0.738 & 98.40 & 0.001 & 0.14 & 0.744 & 99.20 & 0.003 & 0.40 \\
\hline & 1.50 & 1.479 & 98.60 & 0.025 & 1.7 & 1.482 & 98.80 & 0.029 & 1.96 \\
\hline \multirow[t]{2}{*}{ Fish tissue } & 0.75 & 0.742 & 98.90 & 0.002 & 0.27 & 0.740 & 98.70 & 0.001 & 0.14 \\
\hline & 1.50 & 1.487 & 99.10 & 0.02 & 1.34 & 1.479 & 98.60 & 0.009 & 0.61 \\
\hline
\end{tabular}

${ }^{\mathrm{a}}$ Mean of four experiments carried out on the same day

${ }^{b}$ Mean of four experiments carried out on different four day

\section{Linearity}

Linearity of electroanalytical technique is the evaluation of how well calibration plot of electroanalytical response toward concentration approximates a straight line (Buck and Lindner 1994). As known, the standard calibration graph was acquired by measuring five different concentrations of $\mathrm{Hg}$ (II) as standard solutions. It turned out that the electrode potential $[\mathrm{mV}]$ and the logarithm of the $\mathrm{Hg}$ (II) concentration were linearly correlating. Table 1 presents regression data and correlation coefficients $(R)$, together with other statistical parameters.

\section{Detection limit and quantification limit}

The quantification limit (LOQ) is calculated by determining the minimum concentration, which could be detected in accordance with the recommendations of ICH Q2 (R1) (Gumustas and Ozkan 2011); below this value, the calibration function was nonlinear. $5 \times 10^{-8} \mathrm{~mol} / \mathrm{L}$ was the lowest concentration that can be detected by the nominated electrode. LOD is a minimum amount of the evaluated sample (Gumustas and Ozkan 2011). It was well visible from the LOD results presented in Table 1 that the investigated SPE was extremely sensitive and display viable tools for the determination of small $\mathrm{Hg}(\mathrm{II})$ concentrations.

\section{Specificity}

Process specificity could be studied by investigating all interferences encountered from usually occurring cations. It was found that the results of proposed technique have unnoticeable interference with the examined cations according to Table 2 .

\section{Comparison of the proposed $\mathrm{Hg}$ (II)-MSPE sensor and some of the previous reports}

Previously manufactured $\mathrm{Hg}$ (II)-selective electrodes and the current zirconium antimonate-based electrode are reported in Table 5 including the $\mathrm{pH}$ range, response time, slope and dynamic linear range. Clearly, it could be concluded that the studied electrode compared favorably to other ion-selective electrodes described in the literature.

\section{Conclusions}

$\mathrm{Hg}$ (II)-screen-printed electrode based on zirconium antimonite as ionophore and o-NPOE as plasticizer were developed and exhibited good reproducibility for about 4 months in the concentration range of $5.0 \times 10^{-8}-1.0 \times 10^{-1} \mathrm{~mol} / \mathrm{L}$, within the $\mathrm{pH}$ range of 2.5-8.5. The proposed electrode was successfully applied to the determination of $\mathrm{Hg}(\mathrm{II})$ in tap water, river water, industrial wastewaters, waste of dental amalgam and fish tissue samples. The analytical method proposed proved to be simple, rapid and accurate. 
Table 5 Comparing some of the characteristics of $\mathrm{Hg}$ (II)-MSPE with some previously reported $\mathrm{Hg}$ (II)-ISEs

\begin{tabular}{|c|c|c|c|c|c|}
\hline Ionophore & Dynamic range $(\mathrm{mol} / \mathrm{L})$ & Slope (mV/decade) & $\mathrm{pH}$ range & Response time (s) & References \\
\hline Zirconium antimonate & $5 \times 10^{-8}-1 \times 10^{-1}$ & 30.02 & $2.5-8.5$ & $<10$ & This work \\
\hline $\begin{array}{l}N, N \text {-bis(salicylaldehyde)-phenylen- } \\
\text { ediamine }\end{array}$ & $3.2 \times 10^{-7}-3.2 \times 10^{-4}$ & 58.8 & $3.8-7.8$ & $10-270$ & Gupta et al. (2007) \\
\hline $\begin{array}{l}\text { Tetrathia-diazacyclotetradeca- } \\
\text { 2,9-diene }\end{array}$ & $1.4 \times 10^{-6}-1.0 \times 10^{-1}$ & 30 & $2.5-5.0$ & 18 & Singh et al. (2004) \\
\hline Hexathia-18-crown-6-tetraone & $4.0 \times 10^{-6}-1.0 \times 10^{-3}$ & 39 & $0.5-2.0$ & 45 & Agrahari et al. (2014) \\
\hline $\begin{array}{l}\text { 5,11,17,23-Tetra-tert-butyl-25,27-di- } \\
\text { hydroxy-26,28-bis }(O \text {-methyl } \\
\text { glycylcarbonylmethoxy) thiacalix } \\
\text { [4]-arene }\end{array}$ & $5.0 \times \times^{10-8}-1.0 \times 10^{-2}$ & 29.5 & $6.0-7.5$ & 10 & Gupta et al. (2013) \\
\hline 2-Mercaptobenzothiazole & $1.0 \times 10^{-6}-1.0 \times 10^{-1}$ & 28.6 & $0.5-3.5$ & $20-100$ & Mazloum et al. (2000) \\
\hline 1,4,8,11-Tetrathiacyclotetradecane & $1.0 \times 10^{-7}-1.0 \times 10^{-2}$ & 29.6 & $1-3$ & $<60$ & Ion et al. (2009) \\
\hline $\begin{array}{l}\text { Heterogeneous poly }(\mathrm{Hg}(\mathrm{II}) \text {-4-vinyl } \\
\text { pyridine) }\end{array}$ & $1.0 \times 10^{-7}-1.0 \times 10^{-2}$ & 30 & $3-4$ & $<20$ & $\begin{array}{l}\text { Bakhtiarzadeh and Ab Ghani } \\
\text { (2008) }\end{array}$ \\
\hline $\begin{array}{l}\text { Bis[5-((4-nitrophenyl)azo salicyla- } \\
\text { ldehyde)] }\end{array}$ & $7.0 \times 10^{-7}-5.0 \times 10^{-2}$ & 30 & $1.0-3.5$ & $<10$ & $\begin{array}{l}\text { Mashhadizadeh and Sheikh- } \\
\text { shoaie (2003) }\end{array}$ \\
\hline Dibenzodiazathia-18-crown-6-dione & $8.0 \times 10^{-6}-1.0 \times 10^{-2}$ & 29 & $0.5-2.5$ & 10 & Fakhari et al. (1997) \\
\hline $\begin{array}{l}\text { 1,2-Bis(quinolin-8-ylsulfanylme- } \\
\text { thyl)benzene }\end{array}$ & $1.0 \times 10^{-7}-1.0 \times 10^{-2}$ & 29.7 & $1.7-0.4$ & 15 & Kermani et al. (2015) \\
\hline 2-Amino-6-purinethiol & $7.0 \times 10^{-8}-1.0 \times 10^{-1}$ & 30.0 & & 10 & Gupta et al. (2007) \\
\hline Calixarene derivative & $5.0 \times 10^{-5}-1.0 \times 10^{-1}$ & 31.9 & & $<20$ & Mahajan et al. (2008) \\
\hline $\begin{array}{l}\text { Trioctylmethylammonium thiosal- } \\
\text { icylate }\end{array}$ & $1.0 \times 10^{-2}-1 \times 10^{-9}$ & $44.08 \pm 1.0$ & & $<5$ & Ismaiel et al. (2014) \\
\hline $\mathrm{Hg}^{2+}$-ion imprinted polymer & $4.0 \times 10^{-9}-1.30 \times 10^{-3}$ & 29.72 & $3.0-4.5$ & $\sim 5$ & Shirzadmehr et al. (2015) \\
\hline $\begin{array}{l}\text { Poly- } o \text {-toluidine-zirconium phos- } \\
\text { phoborate }\end{array}$ & $1.0 \times 10^{-7}-1.0 \times 10^{-1}$ & 28.0 & $2.5-10$ & 6 & Kaushal et al. (2016) \\
\hline 1-Undecanethiol & $1.0 \times 10^{-8}-1.0 \times 10^{-1}$ & $28.83 \pm 0.4$ & $4.0-6.0$ & 30 & Li et al. (2016) \\
\hline $\mathrm{Hg}(\mathrm{II})-\mathrm{MWCNTs} / \mathrm{Nanosilica-CPE}$ & $1.8 \times 10^{-8}-1.0 \times 10^{-1}$ & 29.92 & $2.5-8.5$ & 4 & Ali and Mohamed (2015) \\
\hline MWCNTs-CPE & $1.0 \times 10^{-7}-1.0 \times 10^{-1}$ & 28.75 & $3.0-7.5$ & 7 & \\
\hline
\end{tabular}

Open Access This article is distributed under the terms of the Creative Commons Attribution 4.0 International License (http://creativeco mmons.org/licenses/by/4.0/), which permits unrestricted use, distribution, and reproduction in any medium, provided you give appropriate credit to the original author(s) and the source, provide a link to the Creative Commons license, and indicate if changes were made.

\section{References}

Afkhami A, Bagheri H, Khoshsafar H, Saber-Tehrani M, Tabatabaee M, Shirzadmehr A (2012) Simultaneous trace-levels determination of $\mathrm{Hg}$ (II) and $\mathrm{Pb}$ (II) ions in various samples using a modified carbon paste electrode based on multi-walled carbon nanotubes and a new synthesized Schiff base. Anal Chim Acta 746:98-106

Agrahari SK, Kumar SD, Srivastava AK (2014) Ion selective electrode for uranium based on composite multiwalled carbon nanotubebenzo-15-crown-5 in PVC matrix coated on graphite rod. J Anal Chem 69(1):36-44

Ali TA, Mohamed GG (2015) Multi-walled carbon nanotube and nanosilica chemically modified carbon paste electrodes for the determination of mercury(II) in polluted water samples. Anal Methods 7(15):6280-6289
Ali TA, Aglan RF, Mohamed GG, Mourad MA (2014) New chemically modified screen-printed electrode for Co (II) determination in different water samples. Int J Electrochem Sci 9:1812-1826

Antropov L (1972) Theoretical electrochemistry. Mir, Moscow

Bagheri H, Gholami A (2001) Determination of very low levels of dissolved mercury(ii) and methylmercury in river waters by continuous flow with on-line uv decomposition and cold-vapor atomic fluorescence spectrometry after pre-concentration on a silica gel2-mercaptobenzimidazol sorbent. Talanta 55:1141-1150

Bakhtiarzadeh F, Ab Ghani S (2008) An ion selective electrode for mercury(II) based on mercury(II) complex of poly(4-vinyl pyridine). J Electroanal Chem 624(1-2):139-143

Bhanjana G, Dilbaghi N, Kumar R, Kumar S (2015) Zinc oxide quantum dots as efficient electron mediator for ultrasensitive and selective electrochemical sensing of mercury. Electrochim Acta 178:361-367

Buck RP, Lindner E (1994) Recommendations for nomenclature of ionselective electrodes (IUPAC recommendations 1994). Pure Appl Chem 66(12):2527-2536

Chen Q, Wu X, Wang D, Tang W, Li N, Liu F (2011) Oligonucleotide-functionalized gold nanoparticles-enhanced QCM-D sensor for mercury (II) ions with high sensitivity and tunable dynamic range. Analyst 136(12):2572-2577

de Wuilloud JCA, Wuilloud RG, Silva MF, Olsina RA, Martinez LD (2002) Sensitive determination of mercury in tap water by cloud point extraction pre-concentration and flow injection-cold

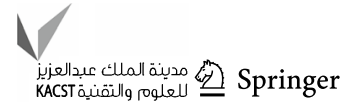


vapor-inductively coupled plasma optical emission spectrometry. Spectrochim Acta Part B 57:365-374

dos Santos EJ, Herrmann AB, Vieira MA, Frescura VLA, Curtius AJ (2005) Evaluation of slurry preparation procedures for the determination of mercury by axial view inductively coupled plasma optical emission spectrometry using on-line cold vapor generation. Spectrochim Acta, Part B 60:659-665

Elkady F, Khodary MA, Zaatout AA (2015) Novel nano-zirconium antimonate as cation exchange material for organic dye pollutants purification. Am J Appl Chem 3(3):46-53

Fakhari AR, Ganjali MR, Shamsipur M (1997) PVC-Based Hexathia18-crown-6-tetraone Sensor for Mercury(II) Ions. Anal Chem 69(18):3693-3696

Ferrúa N, Cerutti S, Salonia JA, Olsina RA, Martinez LD (2007) Online preconcentration and determination of mercury in biological and environmental samples by cold vapor-atomic absorption spectrometry. J Hazard Mater 141(3):693-699

Frag EYZ, Aglan RF, Mohamed HA (2016) Lanthanum(III) potentiometric sensors based on ethyl benzoyl acetate. Arab J Chem. https ://doi.org/10.1016/j.arabjc.2016.11.015

Ghoneim AA, Ameer MA, Saleh HM, El-Taib Heakal FE (1996) Reactivity of the oxide growth process on $\mathrm{Zr}$ metal in aqueous potassium iodide and other alkali halide solutions. Berichte der Bunsen-Gesellschaft fur Physikalische Chemie 100(8):1293-1298

Ghoneim AA, Saleh HM, El-Taib Heakal FE (1998) On the role of iodine in the oxidation of $\mathrm{Zr}$ in $\mathrm{KI}$ medium. Monatsh Chem 129:799-810

Gumustas M, Ozkan SA (2011) The role of and the place of method validation in drug analysis using electroanalytical techniques. Open Anal. Chem. J. 5:1-21

Gupta VK, Singh AK, Al Khayat M, Gupta B (2007) Neutral carriers based polymeric membrane electrodes for selective determination of mercury (II). Anal Chim Acta 590(1):81-90

Gupta VK, Sethi B, Sharma RA, Agarwal S, Bharti A (2013) Mercury selective potentiometric sensor based on low rim functionalized thiacalix [4]-arene as a cationic receptor. J Mol Liq 177:114-118

Gurtova O, Ye L, Chmilenko F (2013) Potentiometric propranololselective sensor based on molecularly imprinted polymer. Anal Bioanal Chem 405(1):287-295

Halbrook RS, Jenkins JH, Bush PB, Seabolt ND (1994) Sublethal concentrations of mercury in river otters: monitoring environmental contamination. Arch Environ Contam Toxicol 27(3):306-310

Ion AC, Ion I, Stefan DN, Barbu L (2009) Possible mercury speciation in urine samples using potentiometric methods. Mater Sci Eng: C 29(1):1-4

Ismaiel A, Aroua M, Yusoff R (2014) A new electrochemical sensor based on task-specific ionic liquids-modified palm shell activated carbon for the determination of mercury in water samples. Sensors 14(7):13102-13113

Jiang X, Gan W, Wan L, Zhang H, He Y (2010) Determination of mercury by electrochemical cold vapor generation atomic fluorescence spectrometry using polyaniline modified graphite electrode as cathode. Spectrochim Acta Part B 65:171-175

Kaushal S, Badru R, Kumar S, Mittal SK, Singh P (2016) Fabrication of a mercury(II) ion selective electrode based on poly-o-toluidinezirconium phosphoborate. RSC Advances 6(4):3150-3158

Kermani SMJD, Ghanei-Motlagh M, Zhiani R, Taher MA, Fayazi M, Razavipanah I (2015) Novel solid-state mercury(II)-selective electrode based on symmetrical sulfur-containing carrier. J Mol Liq 206:145-150

Lau OW, Ho SY (1993) Simultaneous determination of traces of iron, cobalt, nickel, copper, mercury and lead in water by energy-dispersive X-ray fluorescence spectrometry after preconcentration as their piperazino-1,4-bis(dithiocarbamate) complexes. Anal Chim Acta 280:269-277
Li XQ, Liang HQ, Cao Z, Xiao Q, Xiao ZL, Song LB, Chen D, Wang FL (2016) Simple and rapid mercury ion selective electrode based on 1-undecanethiol assembled Au substrate and its recognition mechanism. Mater Sci Eng: C 72:26-33

Lou XH, Zhao T, Liu R, Ma JS, Xiao Y (2013) Self-assembled DNA monolayer buffered dynamic ranges of mercuric electrochemical sensor. Anal Chem 85(15):7574-7580

Ma F, Sun M, Zhang K, Wang S (2015) A ratiometric fluorescence sensor for highly selective and sensitive detection of mercuric ion. Sens Actuators B Chem 209:377-383

Manahan SE (1979) Environmental chemistry, 3rd edn. Willard Grant Press, Boston, Massachusetts, pp 150-151

Mahajan R, Kaur R, Bhalla V, Kumar M, Hattori T, Miyano S (2008) Mercury(II) sensors based on calix[4]arene derivatives as receptor molecules. Sens Actuators B: Chem 130(1):290-294

Martinis EM, Bertón P, Olsina RA, Altamirano JC, Wuilloud RG (2009) Trace mercury determination in drinking and natural water samples by room temperature ionic liquid based-preconcentration and flow injection-cold vapor atomic absorption spectrometry. $\mathrm{J}$ Hazard Mater 167:475-481

Mashhadizadeh MH, Sheikhshoaie I (2003) Mercury(II) ion-selective polymeric membrane sensor based on a recently synthesized Schiff base. Talanta 60(1):73-80

Matousek JP, Iavetz R, Powell KJ, Louie H (2002) Mechanistic studies on the trapping and desorption of volatile hydrides and mercury for their determination by electrothermal vaporization-inductively-coupled plasma mass spectrometry. Spectrochim Acta Part B 57:147-155

Mazloum M, Amini MK, Mohammadpoor-Baltork I (2000) Mercury selective membrane electrodes using 2-mercaptobenzimidazole, 2-mercaptobenzothiazole, and hexathiacyclooctadecane carriers. Sens Actuators B: Chem 63(1-2):80-85

Oesch U, Simon W (1980) Lifetime of neutral carrier based ion-selective liquid-membrane electrodes. Anal Chem 52(4):692-700

Raulf M, Buschmann N, Sommer D (1995) Determination of anionic surfactants in lubrication fluids. Fresenius' J Anal Chem 351(56):526-529

Riley RG, Zachara JM, Wobber FJ (1992) Chemical contaminants on DOE lands and selection of contaminant mixtures for subsurface science research, U.S. Department of Energy, Office of Energy Research, Washington, DC (DOE/ER-0547T)

Sadeghi S, Dashti GR, Shamsipur M (2002) Lead-selective poly (vinyl cholride) membrane electrode based on piroxicam as a neutral carrier. Sens Actuators B Chem 81(2):223-228

Shirzadmehr A, Afkhami A, Madrakian T (2015) A new nano-composite potentiometric sensor containing an $\mathrm{Hg} 2+$-ion imprinted polymer for the trace determination of mercury ions in different matrices. J Mol Liq 204:227-235

Singh AK, Bhattacharjee G, Singh R (2004) Mercury(II)-selective membrane electrode using tetrathia-diazacyclotetradeca-2,9-diene as neutral carrier. Sens Actuators B: Chem 99(1):36-41

Umezawa Y, Umezawa K, Sato H (1995) Selectivity coefficients for ion-selective electrodes: recommended methods for reporting values. Pure Appl Chem 67:507-518

Umezawa Y, Buhlmann P, Umezawa K, Tohda K, Amemiya S (2000) Potentiometric selectivity coefficients of ion-selective electrodes part I. Inorganic cations (technical report). Pure Appl Chem 72(10):1851-2082

WH Organization (2004) Guidelines for drinking-water quality: recommendations. World Health Organization

Wuilloud JCA, Wuilloud RG, Vonderheide AP, Caruso JA (2004) Gas chromatography/plasma spectrometry-a important analytical tool for elemental speciation studies. Spectrochim Acta Part B $59: 755-792$ 
Zavvar Mousavi H, Asghari A, Shirkhanloo H (2010) Determination of $\mathrm{Hg}$ in water and wastewater samples by $\mathrm{cv}$-aas following online preconcentration with silver trap. J Anal Chem 65:935-939

Zi HJ, Gan WE, Han SP, Jiang XJ, Wan LZ (2009) Determination of trace inorganic mercury in mineral water by flow injection on-line sorption preconcentration-cold vapor atomic fluorescence spectrometry. Chin J Anal Chem 37:1029-1032
Publisher's Note Springer Nature remains neutral with regard to jurisdictional claims in published maps and institutional affiliations. 